\title{
THE PSYCHOLOGICAL STRATEGIES USED BY MALAYSIAN NATIONAL RUGBY PLAYERS DURING ASIAN 5 NATIONS RUGBY TOURNAMENT 2015
}

\author{
Mazlan Ismail ${ }^{1+}$ \\ Dohammad \\ Rahizam Abdul \\ Rahim $^{2}$ \\ Sharina Salmi \\ Azmi $^{3}$
}

\author{
${ }^{\prime}$ Faculty of Sports Science and Recreation, Universiti Telnologi MARA, \\ Negeri Sembilan, Malaysia \\ Email:mazlan2154@ns.uitm.edu.my \\ ${ }^{2}$ Faculty of Sports Science and Recreation, Universiti Teknologi MARA, \\ Shah Alam, Malaysia \\ Email:mrrahizam@salam.uitm.edu.my \\ 'Academy of Language Studies, Universiti Teknologi MARA, Negeri \\ Sembilan, Malaysia \\ Email:Shari179@ns.uitm.edu.m
}

Th) Check for updates

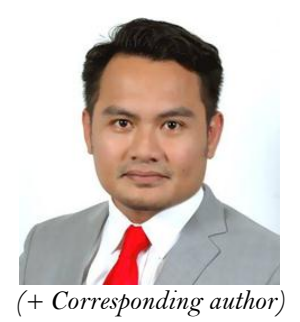

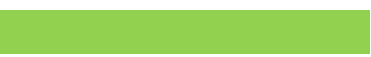

Article History

Received: 14 March 2018 Revised: 9 April 2018

Accepted: 11 April 2018 Published: 13 April 2018

\section{Keywords}

Psychological performance Strategies

Rugby

Playing position

Practice

Competition
The main purpose of this study is to obtain the psychological performance strategies used by Malaysian national rugby players during Asian 5 Nations Rugby Tournament 2015. All twenty-nine participants of this study are trained and experienced male players within the age of 19 to 38 years. Each player was given a set of Test of Performance Strategies (TOPS) questionnaire, which consisted of 64 items seeking the respondents to state the psychological strategy they use towards themselves during competition and practice during the match. The results showed significant difference only in emotional control strategy during practice condition. Due to specific demand in position, the backline-position players used emotional control as a strategy more often during practice, compared to the forward-position players. Meanwhile, in competition condition the performance strategies were equally used for both positions. The findings suggest that to win a game, both positions (forward and backline) have to use similar strategies, particularly in team sports. Future study should examine the strategies adopted in several investigations in order to derive comparisons among other professional teams.

\section{INTRODUCTION}

In recent years, several mental aptitude inventories have been proposed (Thomas et al., 1999) including metaanalyses that indicate that psychological practice produces measureable additions in talented execution, particularly for cognitive and physical assignments (Feltz and Landers, 1983; Driskell et al., 1994).

Competitive anxiety has been defined as a combination of cognitive anxiety, somatic anxiety, and selfconfidence (Martens et al., 1990). Even professional athletes admit that they feel nervous when performing in front of thousands of spectators (Mazlan and Mustaza, 2014). Anxiety has also been found to be more intense during competition than during pre-competition because anxiety is caused by external aspects, such as the physique of opponents, the huge number of spectators, and the intense feeling of responsibility towards coaches and family. A sport psychologist thus will usually recommend increasing the motivation and goal-setting of athletes, believing that such efforts would increase the athletes' performances and facilitate determining successful and unsuccessful athletes by their psychological skills. 
Previous researchers have recommended that athletes be urged to enhance their skills performance intrinsically by using self-psychological strategies instead of extrinsic inspiration in order to facilitate achieving particular tasks (Rushall, 1992). However, these performance psychological strategies are not suitable in all conditions. For example, one study has found that the anxiety levels of goalkeepers were higher than that of other positions (i.e. defenders, midfield), and that goalkeepers also demonstrated less self-confidence than did the defenders (Sewell and Edmondson, 1970). This discovery were attested in a recent research, which found that defenders and goal keepers were better than strikers and midfielders in goal-setting strategies (Mazlan and Mustaza, 2014). The relationship between sport psychological skills and different playing positions is also stated as an important research area (Sweata and Remon, 2013). Performance strategies must perfectly fit the needs of an athlete based on his or her position on field, and nature and intensity of game. For example, imagery, activation, and goal setting methods are more frequently used by professional athletes compared to novice athletes (Thomas et al., 1999).

One study conducted by D’Urso et al. (2002) on rugby players found that emotions were modified widely during a game due to external events (e.g., behavior of teammates or opponents) or individual behaviors (e.g., individual faults). Another study by Hodge et al. (2008) used self-determination theory by Deci and Ryan (2002) to identify the motivational level among elite rugby players. The study concludes that the competence and autonomy scores of high burnout elite rugby players were low compared to players with low burnout symptoms. Previous study also found that team-sports athletes had lower emotional control than individual athletes during practice and competition (Dachen, 2012). Recent study conducted by Mazlan and Afizan (2016) revealed no significant difference in the anxieties states of the university rugby players between backs and forwards positions. However, the players demonstrated higher level of cognitive and somatic anxieties before the first game compared to second game (Mazlan and Afizan, 2016). No study thus far has revealed the mental strategies used by Malaysian national rugby players during practice and competition. Therefore, the purpose of this study was to recognize the performance strategies used by Malaysian national rugby players, particularly in different positions of play, during Asian 5 Nations Competition 2015.

\section{METHODOLOGY}

\subsection{Participants}

Data for the study were collected from twenty-nine Malaysian national rugby players, aged 19 to 38 years $(M$ $=25.72, S D=4.38)$. The participants were sampled from different positions on the pitch (16 forward and 13 backline) and all players were competing in the Asian 5 Nations Rugby Competition 2015 at the time of data collection.

Test of Performance Strategies. The participants completed the Test of Performance Strategies (TOPS) questionnaire during the Asian 5 Nations Rugby Tournament 2015 competition. It consists of two scales, practice and competition with 64-item self-report instrument designed by Thomas et al. (1999). The questionnaire served to measure the psychological skills and strategies used by the athletes during practice and in competition. The practice subscales were self-talk (maintaining a positive internal dialogue), emotional control (controlling emotions under pressure), automaticity (performing with little conscious effort, automatically), goal-setting (setting personal, specific goals), imagery (visualizing sport performance), activation (maintaining an optimal level of arousal), relaxation (practicing to remain calm under pressure), and attentional control (focusing attention effectively). Meanwhile, the competition subscales were the same, except attention control, which was replaced by negative thinking (thoughts of failure). In the present study, the Cronbach alpha coefficient was .70. Finally, descriptive statistic and independent sample t test were performed to compare the performance strategies adopted in different positions. 


\section{RESULTS}

The preliminary assumption was conducted and the data was normally distributed. Descriptive statistics for performance strategies during practices and competitions are presented in Table 1 and Table 2 . An Independent ttest result in Table 1 shows significant differences only in emotional control scores during practice condition for forward $(M=9.12, S D=1.89)$ and backline $(M=9.31, S D=3.20 ; t(29)=-.1 .82, p=.015$, two -tailed $)$. The magnitude of the differences in the means (means difference $=-.183,95 \%$ CI: -2.29 to -1.93 ) is moderate (eta squared $=.07)$. In competition condition, the Independent t-test result in Table 2 shows that there was no significant difference in the performance strategies used by Malaysian national rugby players (forward and backline).

Table-1. Independent t-test for differences position on the pitch between forward and backline among Malaysian national rugby players for performance strategies during practice condition

\begin{tabular}{|c|c|c|c|c|c|c|c|c|c|}
\hline Variable & Position & $\mathbf{N}$ & Mean & SD & $\mathbf{t}$ & df & p-value & $\begin{array}{l}\text { Mean } \\
\text { difference }\end{array}$ & $\begin{array}{l}\text { Std. Error } \\
\text { difference }\end{array}$ \\
\hline \multirow[t]{2}{*}{ Goal setting } & Forward & 16 & 13.06 & 2.35 & \multirow[t]{2}{*}{-1.23} & \multirow[t]{2}{*}{27} & \multirow[t]{2}{*}{.06} & \multirow[t]{2}{*}{-1.32} & \multirow[t]{2}{*}{1.08} \\
\hline & Backline & 13 & 14.38 & 3.43 & & & & & \\
\hline \multirow{2}{*}{$\begin{array}{l}\text { Emotional } \\
\text { control }\end{array}$} & Forward & 16 & 9.12 & 1.89 & \multirow[t]{2}{*}{-.18} & \multirow[t]{2}{*}{18.6} & \multirow[t]{2}{*}{$.01^{*}$} & \multirow[t]{2}{*}{-.18} & \multirow[t]{2}{*}{1.01} \\
\hline & Backline & 13 & 9.31 & 3.20 & & & & & \\
\hline \multirow[t]{2}{*}{ Automaticity } & Forward & 16 & 15.56 & 3.18 & \multirow[t]{2}{*}{-.48} & \multirow[t]{2}{*}{27} & \multirow[t]{2}{*}{.59} & \multirow[t]{2}{*}{-.59} & \multirow[t]{2}{*}{1.24} \\
\hline & Backline & 13 & 16.13 & 3.48 & & & & & \\
\hline \multirow[t]{2}{*}{ Relaxation } & Forward & 16 & 13.94 & 1.91 & \multirow[t]{2}{*}{.02} & \multirow[t]{2}{*}{27} & \multirow[t]{2}{*}{.25} & \multirow[t]{2}{*}{.01} & \multirow[t]{2}{*}{.93} \\
\hline & Backline & 13 & 13.92 & 3.09 & & & & & \\
\hline \multirow[t]{2}{*}{ Self-talk } & Forward & 16 & 14.75 & 3.19 & \multirow[t]{2}{*}{-1.42} & \multirow[t]{2}{*}{27} & \multirow[t]{2}{*}{.84} & \multirow[t]{2}{*}{-1.71} & \multirow[t]{2}{*}{1.21} \\
\hline & Backline & 13 & 16.46 & 3.28 & & & & & \\
\hline \multirow[t]{2}{*}{ Imagery } & Forward & 16 & 14.25 & 2.3 & \multirow[t]{2}{*}{-1.29} & \multirow[t]{2}{*}{27} & \multirow[t]{2}{*}{.53} & \multirow[t]{2}{*}{-1.29} & \multirow[t]{2}{*}{1.00} \\
\hline & Backline & 13 & 15.54 & 3.1 & & & & & \\
\hline Attention & Forward & 16 & 12.94 & 1.98 & -.87 & 27 & .90 & -.68 & .78 \\
\hline control & Backline & 13 & 13.62 & 2.22 & & & & & \\
\hline Activation & Forward & 16 & 12.69 & 1.92 & -1.32 & 27 & .42 & -1.01 & .76 \\
\hline & Backline & 13 & 13.69 & 2.18 & & & & & \\
\hline
\end{tabular}

*significant at $\mathrm{p}<0.05)$

Table-2. Independent t-test for different position on the pitch between forward and backline among Malaysian national rugby players for performance strategies during competition condition

\begin{tabular}{|c|c|c|c|c|c|c|c|c|c|}
\hline Variable & Position & $\mathbf{N}$ & Mean & SD & $\bar{t}$ & df & $\begin{array}{l}\text { p- } \\
\text { value }\end{array}$ & $\begin{array}{l}\text { Mean } \\
\text { difference }\end{array}$ & $\begin{array}{l}\text { Std. Error } \\
\text { difference }\end{array}$ \\
\hline \multirow[t]{2}{*}{ Goal setting } & Forward & 16 & 15.36 & 3.26 & \multirow[t]{2}{*}{-1.16} & \multirow[t]{2}{*}{27} & \multirow[t]{2}{*}{.33} & \multirow[t]{2}{*}{-1.13} & \multirow[t]{2}{*}{1.13} \\
\hline & Backline & 13 & 16.70 & 2.72 & & & & & \\
\hline \multirow{2}{*}{$\begin{array}{l}\text { Emotional } \\
\text { control }\end{array}$} & Forward & 16 & 11.63 & 2.78 & \multirow[t]{2}{*}{-.81} & \multirow[t]{2}{*}{27} & \multirow[t]{2}{*}{.99} & \multirow[t]{2}{*}{-.84} & \multirow[t]{2}{*}{1.03} \\
\hline & Backline & 13 & 12.46 & 2.76 & & & & & \\
\hline \multirow[t]{2}{*}{ Automaticity } & Forward & 16 & 14.44 & 2.83 & \multirow[t]{2}{*}{-.93} & \multirow[t]{2}{*}{27} & \multirow[t]{2}{*}{-.89} & \multirow[t]{2}{*}{-1.02} & \multirow[t]{2}{*}{1.11} \\
\hline & Backline & 13 & 15.46 & 3.13 & & & & & \\
\hline \multirow[t]{2}{*}{ Relaxation } & Forward & 16 & 10.44 & 2.46 & \multirow[t]{2}{*}{1.11} & \multirow[t]{2}{*}{27} & \multirow[t]{2}{*}{.48} & \multirow[t]{2}{*}{1.13} & \multirow[t]{2}{*}{1.03} \\
\hline & Backline & 13 & 11.15 & 3.07 & & & & & \\
\hline \multirow[t]{2}{*}{ Self-talk } & Forward & 16 & 14.94 & 2.77 & \multirow[t]{2}{*}{-.69} & \multirow[t]{2}{*}{27} & \multirow[t]{2}{*}{.69} & \multirow[t]{2}{*}{-.76} & \multirow[t]{2}{*}{1.09} \\
\hline & Backline & 13 & 15.69 & 3.12 & & & & & \\
\hline \multirow[t]{2}{*}{ Imagery } & Forward & 16 & 13.31 & 2.75 & \multirow[t]{2}{*}{-2.00} & \multirow[t]{2}{*}{27} & \multirow[t]{2}{*}{.96} & \multirow[t]{2}{*}{-2.07} & \multirow[t]{2}{*}{1.04} \\
\hline & Backline & 13 & 15.38 & 2.81 & & & & & \\
\hline Negative & Forward & 16 & 10.75 & 2.46 & 1.11 & 27 & .48 & 1.13 & 1.03 \\
\hline thinking & Backline & 13 & 9.62 & 3.07 & & & & & \\
\hline Activation & Forward & 16 & 15.31 & 2.85 & .01 & 27 & .74 & .01 & 1.03 \\
\hline & Backline & 13 & 15.31 & 2.63 & & & & & \\
\hline
\end{tabular}




\section{DISCUSSION}

The aim of the present study was to obtain the psychological performance strategies used by Malaysian national rugby players in practice and competition condition during Asian 5 Nations Rugby Tournament 2015. Independent sample $t$ test was conducted to determine if any significant differences existed between forward and backline in terms of the performance strategies used during practice and competition conditions. The findings revealed that certain positions on the pitch showed differences in the performance strategies used by forward and backline only during the practice condition. For example, compared to forward positions, backline positions used more emotional control strategies during practice. According to Pensgaard and Roberts (2003) emotion-focused coping strategies are aimed to diminish undesirable physical and emotional arousal. These strategies incorporate systems, for example, mental and behavioural withdrawal, refusal, or acknowledgment. The players in forward positions were also found to use less emotional control to maintain their aggressive nature of play on the field. As mentioned by D'Urso et al. (2002) the emotional changes of rugby players depend on their teammates and team oppositions before the actual match. More importantly, the present study found that the performance strategies were equally used by both positions (backline and forward) to win the game as well as to play as a team. Correspondingly, one previous study found no difference of pre-competitive anxieties in rugby positions between backs and forwards before competition (Mazlan and Afizan, 2016).

Further research should include strategies in more than one investigation and comparisons between other professional teams or national teams, i.e., matches during the whole season should be conducted too. The present findings, hopefully, will help coaches and sports psychologist to design more effective psychological skills training that include cognitive coping strategies, self-talk, relaxation, imagery, and thought control to deal with stress and anxiety rather than focusing merely on technical and tactical aspects of a game, For example, the PIM training programme helps to improve the psychological variables and skills performance of the athletes (Mazlan, 2015;2016; Mazlan, 2016; Nur and Mazlan, 2016). It is of utmost importance for sport psychologists to design their mental training programme with specific and attainable goals that can fulfil a team's requirements.

Funding: This study received no specific financial support.

Competing Interests: The authors declare that they have no competing interests.

Contributors/Acknowledgement: All authors contributed equally to the conception and design of the study.

\section{REFERENCES}

D’Urso, V., A. Petrosso and C. Robazza, 2002. Emotions, perceived qualities, and performance of rugby players. Sport Psychologist, 16(2): 173 - 199. View at Google Scholar | View at Publisher

Dachen, J., 2012. Test or performance strategies among college going athletes: Differences across type of sports and gender. International Journal of Behavioural Social and Movement Sciences, 1(4): 139 - 147. View at Google Scholar

Deci, E.L. and R.M. Ryan, 2002. Self-determination research: Reflections and future directions. In E. L. Deci \& R. M. Ryan (Eds.), Handbook of self-determination research. Rochester, NY: University of Rochester Press. pp: 431-441.

Driskell, J.E., C. Copper and A. Moran, 1994. Does mental practice enhance performance. Journal of Applied Psychology, 79(4): 481-492. View at Google Scholar | View at Publisher

Feltz, D.L. and D.M. Landers, 1983. The effects of mental practice on motor skills, learning and performance: A meta-analysis. Journal of Sport Psychology, 5(1): 25-57. View at Google Scholar | View at Publisher

Hodge, K., C. Lonsdale and Y.Y.N.G. Johan, 2008. Burnout in elite rugby: Reationship with basic psychologcial needs fulfilment. Journal of Sports Scences, 26(8): 835 - 844. View at Google Scholar $\mid$ View at Publisher

Martens, R., D. Burton, R.S. Vealey, L.A. Bump and D.E. Smith, 1990. Development and validation of the competitive state anxiety inventory-2. In R. Martens, R. S. Vealey, \& D. Burton (Eds.), Competitive anxiety in sport. Champaign, IL: Human Kinetics. pp: 117-190 
Mazlan, I., 2015. The idea of using PIM training program to improve self-efficacy of the golfers. International Journal of Enhanced Research in Education Development, 3(2): 2320-8708. View at Google Scholar

Mazlan, I., 2016. PIM' training with e-putting imagery script helps to improve putting scores and moods of the golfers, is this really true. In S.I Ismail et al. (Eds.), Proceedings of the 2nd International Colloquium on Sports Science, Exercise, Engineering and Technology 2015 (Icosseet 2015). pp: 15-23.

Mazlan, I. and A. Afizan, 2016. University rugby sevens players anxiety and confident scores between first game and second game based on different position of play. International Journal of Psychology and Behavioral Sciences, 6(2): 53 - 57. View at Google Scholar | View at Publisher

Mazlan, I. and A. Mustaza, 2014. Malaysian professional university soccer players performance strategies based on positions of play. International Journal of Enhanced Research in Educational Development, 2(4): 80-83. View at Google Scholar

Nur, A.H. and I. Mazlan, 2016. The effects of practice in mind (PIM) training on netball standing shooting performance. Proceedings of the 4th Global Summit on Education. pp: 215-221.

Pensgaard, A.M. and G.C. Roberts, 2003. Achievement goal orientations and use of coping strategies among winter olympians. Psychology of Sport and Exercise, 4(2): 101-1 16. View at Google Scholar $\mid$ View at Publisher

Rushall, B.S., 1992. Mental skills training for sports: A manual for athletes, coaches, and sport psychologists. Australian: Sport Science Associates.

Sewell, D.F. and A.M. Edmondson, 1970. Relationships between field position and pre-match competitive state anxiety in soccer and field hockey. International Journal of Sport Psychology, 27(2): 159-172.

Sweata, B. and C. Remon, 2013. A study on the relationship between anxiety and playing positions of Indian football. Iamr Journal of Physiotheraphy, 2(1): 11-17.

Thomas, P., S. Murphy and L. Hardy, 1999. Test of performance strategies: Development and preliminary validation of a comprehensive measure of athletes' psychological skills. Journal of Sports Sciences, 17(9): 697 - 711 . View at Google Scholar | View at Publisher

Views and opinions expressed in this article are the views and opinions of the author(s), International Journal of Asian Social Science shall not be responsible or answerable for any loss, damage or liability etc. caused in relation to/arising out of the use of the content. 